\title{
Attempt to assess the physical fitness of elderly patients eligible for resection of lung parenchyma using the Fullerton test
}

\author{
Monika Bal-Bocheńska1,2, Wojciech Kądziołka ${ }^{1}$, Joanna Kądziołka \\ ${ }^{1}$ Specialist Team of Tuberculosis and Lung Diseases in Rzeszów \\ ${ }^{2}$ Faculty of Medicine, University of Rzeszów
}

Kardiochirurgia i Torakochirurgia Polska 2013; 10 (4): 435-440

\begin{abstract}
Aim: To evaluate physical fitness with the Fullerton test in patients referred for thoracic procedures.

Material and methods: The study included 35 patients aged 60-70 years (mean 66.8 years): 17 women and 18 men. Physical fitness was assessed using a test for the elderly (Fullerton Rikli \& Jones).

Results: The Fullerton test was well tolerated by thoracic surgery patients. During the study, and immediately afterwards, there was no shortness of breath, fainting, loss of saturation or deterioration of well-being of patients. Most patients showed an improvement in spirometric values (vital capacity - VC\% to $20 \%$, forced expiratory volume in one second $\%$ of vital capacity - $\mathrm{FEV}_{1} \% \mathrm{VC}$ of $\left.22 \%\right)$. There was a positive hemodynamic response in systolic blood pressure (50-80\%) and heart rate $(77-90 \%)$ rated the most serious attempts to determine aerobic endurance and strength endurance of the upper and lower body.

Conclusions: The Fullerton test can be safely used in patients referred for thoracic procedures. As a new, reproducible method of testing, it can complement the comprehensive diagnosis of patients undergoing surgery.

Key words: pulmonary rehabilitation, resection of parenchyma, Fullerton fitness test.
\end{abstract}

\section{Introduction}

According to the WHO definition, a person more than 65 years of age is in a period called old age. In this group of patients, a reduction in physical activity, characterized by a dialing form on the active passive recreation. For many it is a time tested negative changes that necessitate the development of new attitudes to life. Stereotypes associated with the belief that the period of old age is a time of well-de-

\section{Streszczenie}

Cel pracy: Ocena przydatności testu sprawności fizycznej Fullerton u pacjentów kwalifikowanych do zabiegów torakochirurgicznych.

Materiat i metody: Badaniem objęto 35 pacjentów w wieku 60-70 lat (średnia wieku 66,8 roku), w tym 17 kobiet i 18 mężczyzn. Sprawność fizyczną oceniano za pomocą testu Fullerton dla osób starszych, opracowanego przez Roberta E. Rikli i C. Jessie Jones (Rikli \& Jones).

Wyniki: Test Fullerton był dobrze tolerowany przez pacjentów torakochirurgicznych. $W$ trakcie badania i bezpośrednio po nim nie odnotowano uczucia duszności, omdleń, spadku saturacji ani pogorszenia samopoczucia chorych. U większości pacjentów wykazano poprawę wartości spirometrycznych (VC\% o 20\%, $\mathrm{FEV}_{1} \% \mathrm{VC}$ o $22 \%$ ). Zanotowano wzrost skurczowego ciśnienia tętniczego (50-80\%) i przyspieszenie akcji serca (77-90\%) ocenianych po najcięższych próbach określających wytrzymałość tlenową oraz wytrzymałość siłową górnej i dolnej części ciała. Wnioski: Test Fullerton może być bezpiecznie stosowany u pacjentów kwalifikowanych do zabiegów torakochirurgicznych. Jako nowa, powtarzalna metoda badawcza może stanowić uzupełnienie kompleksowej diagnostyki chorych przygotowywanych do zabiegu chirurgicznego.

Słowa kluczowe: rehabilitacja oddechowa, resekcja miąższu, test Fullerton.

served rest, favor limiting physical activity in daily life. Lack of regular physical activity leads to a reduction of efficiency of the body. In this group there is observed a high incidence of diseases of the cardiovascular (75\%), musculoskeletal (68\%), and respiratory (46\%) systems. Important role in reducing the physical activity changes play in the system, in particular a decrease in muscle strength and changes in osteo-articular structures. There is a reduction in the adaptability of the car-

Address for correspondence: Monika Bal-Bocheńska, Specialist Team of Tuberculosis and Lung Diseases in Rzeszów, Rycerska 2 ,

35-241 Rzeszów, e-mail: moniabb@vp.pl 
diovascular system resulting from baroreceptor dysfunction, decreased venous return, and peak oxygen consumption. In the respiratory tract is reducing the movables thoracic, flexibility decrease airway ventilating and increase the growth of dead space. In addition, there is a reduction in activity of muco-ciliary apparatus and the cough reflex. Due to limitations in physical fitness and functional capacity of older people, preparation of the rehabilitation process must be based on an individual examination. An important organ is the physiotherapist to individually exercise program to prepare for thoracic procedures. So far, the methods used were based on the Barthel index or Lawton scale, which did not include the patient's practical physical measurements, i.e. reaction time, flexibility, coordination and strength $[1,2]$. Therapists' work with this distinctive group of patients led to many trials and eventually development of such a test. The U.S.A. in California in the Department of Life Length specialists Robert E. Rikli and C. Jessie Jones created a set of six trials investigating the efficiency of virtually ward, under the name of Fullerton. It requires no special equipment, so it is possible to perform not only in specialized medical institutions. The Fullerton test makes it possible to assess not only the parameters associated with cardio-pulmonary exercise capacity of the body, but the ability to solve human motor tasks and the ability to efficiently and cost effectively carry out the work efficiency of the muscle that is focused on health. Its application allows you to plan and monitor the process of streamlining the process and the desired effect.

\section{Aim}

Preparation of a patient for surgical procedures aims to minimize the risk of complications in the early postoperative period. All investigations should be the basis for further cooperation in the postoperative period. In order to prepare comprehensive patient Fullerton test we used to examine and measure the efficiency and the patient's functional capacity in all directions. Put on the question of whether preparatory rehabilitation can result in increased physical performance and increased spirometric parameters of patients eligible for surgery thoracic surgery, and the Fullerton test is useful in assessing the efficiency of this group of patients.

\section{Material and methods}

The study was conducted in the period from 03.10.2011 until 01.02.2012, in the Laboratory of Physical Therapy Specialist Team of Tuberculosis and Lung Diseases in Rzeszow. The study included 35 patients aged 60-70 years (mean 66.8 years), among them 17 women and 18 men. Physical performance was evaluated by a test for the elderly (Fullerton Rikli \& Jones). These patients have reduced values of spirometry in the first study, eligible for surgical procedures, where the average vital capacity (VC\%) was 62\% and forced expiratory volume in one second \% of vital capacity (FEV ${ }_{1} \% \mathrm{VC}$ ) stood at $68 \%$. Spirometric values found before surgery needed to try to improve these parameters through exercises in the physiotherapy and the use of medications to improve the function of the respiratory and circulatory system. Lack of improvement in respiratory function disqualifies a patient after surgery or exposes the patient to very serious complications after surgery [3]. Patients with lower spirometric values require more preparation in the physiotherapy program individually tailored according to each patient. Physical fitness tests were carried out by one physiotherapist in the studio of rehabilitation. Each of the tasks of the test words is described, and then demonstrated by the investigator. According to the rules of conduct during the exercise testing, before the test and after its completion, blood pressure and heart rate were measured [4, 5].

Fullerton physical fitness test consists of the following six motor tasks:

1. Stand up and go (SG) - to coordinate complex "eight feet" - evaluating the agility and dynamic balance. The task of the patient as soon as possible the creation of the chair, and bypass the cone at a distance of $2.44 \mathrm{~m}$ and return to the sitting position on the chair. The trial begins in a sitting position on a chair. Hands are placed on the knees and the feet on the ground. The signal conducting the test as soon as possible gets up from his chair and beat a designated distance. The test is repeated twice to the nearest 0.1 seconds to choose a better time.

2. Stand up and sit down (SUSD) - Evaluation of strength endurance of lower body. The trial begins with sitting on a chair, feet based on the ground, hands crossed on the chest. The signal leading to repeat the test performed standing up and sitting down in 30 seconds. If time passes, the test is in the upright position, the rise is treated as a full trial and included in the study. The number of repetitions is the result of the test.

3. Lift the weight (LW) - Evaluation of strength endurance of the upper body. The patient sits on the edge of a stable chair set at height $44 \mathrm{~cm}$, back is straight, feet flat on the ground. The dominant hand holds a weight of $2 \mathrm{~kg}$ for women and $3.5 \mathrm{~kg}$ for men. The arm is directed downwards by the chair perpendicular to the floor. At a signal from the patient's upper leg bent at the elbow and supination of the forearm, and then straighten to the starting position. The test result is the number of correctly performed deflections of the forearm for 30 seconds.

4. Reach hand foot (RHF) - assessing the flexibility of the lower body. Trying flexible lower body - "sit and reach out". The patient sits on the edge of a chair. One of the lower limbs is based on the ground heel, ankle bent at an angle of 90 degrees relative to the lower leg. The second lower limb is based on the rate base. The test consists in carrying forward slope maintaining the spine in the most upright position, with the head in the axis of the spine. The arms are pulled forward and the hands placed one on the other. The test tries to touch his fingers toes. Range of flexion should be maintained for 2 seconds. The test result is the distance measured between the middle finger of the hand and the first toe to the nearest $0.5 \mathrm{~cm}$. 
5. Bind his hands $(\mathrm{BHH})$ - assessing the flexibility of the upper body. Flexibility test of the upper body - "scratching the back" - is carried out in a standing position. The dominant hand is assumed to be the same shoulder, heading straight fingers down as far as possible. The second hand is assumed to be back, palmar side out, pulling the toes up, trying to touch the fingers of the other hand. The result of the test is the distance measured between the middle fingers of your hand. If your fingers overlap, then the value is positive, "+", if not negative, "-". The results are accurate to within $0.5 \mathrm{~cm}$. The better result from two trials is chosen.

6. 6-minute walk test (6MWT) - assessing aerobic capacity. The task of the patient is to achieve the longest walking distance in 6 minutes. The test involves marching back and forth on a 30-meter section of a hospital corridor, adjusting the pace of walking to the patient's abilities. Distance traveled is estimated with an accuracy of 1 meter. The result is the distance covered in 6 minutes at the fastest possible pace. The test is very simple to perform; you are moving on a flat surface. The march may be interrupted for a moment when the patient needs to rest and then resumed. It should stop if the patient indicates the following symptoms: dizziness, significant fatigue, pain, severe shortness of breath. Prior to and at the end of the test blood pressure and heart rate are measured.

The first time a test of Fullerton patients attended for a period of 5-10 days (mean 7 days) in the rehabilitation of preparation. Rehabilitation was terminated at the time of obtaining the patient's desired results. Exercises were held in the physiotherapy in groups of 3-5 people in the morning hours, five times a week for 35 minutes. In addition, in the afternoon there was used in this group cycle ergometer training under the care of a physiotherapist, 20 minutes: cycling without a load -3 minutes warm-up, 15-minute basic cycling, two-minute cycling with no load at the end of the training session.

The exercises included:

1. Kinesitherapy:

- breathing exercise track mixed;

- breathing exercise for the lower ribs, front and side sections;

- general exercise development with particular emphasis on:

- rim joints of the upper limbs vertebral joints finned,

- chest exercise to improve muscle strength: intercostal and abdominal exercise with thoracic correction;

- diaphragmatic breathing exercises helped by the abdominal muscles;

- diaphragmatic breathing exercises with resistance [6].

2. Patient education:

explanation of the purpose of rehabilitation exercises; discuss the techniques of mentioned exercises; learn self-control and self-esteem while exercising; no smoking [7].
After completion of the rehabilitation of the second trial was Fullerton and spirometry (VC\%, FEV $\%$ VC).

\section{Statistical analysis}

Data from the study were quantitative. They are presented as the arithmetic mean and standard deviation. Due to the fact that most of these data were not normally distributed, for the verification of statistical hypotheses nonparametric tests were used. Analysis of the differences between the mean values for the group were performed using Student's $t$-test for unrelated samples.

\section{Results}

The proposed Fullerton test was well tolerated by patients qualified for thoracic procedures. All subjects performed the task: a test of physical fitness. During the study, and immediately after, there was no shortness of breath, irregular heart beat or a patient feeling unwell.

In order to evaluate the safety of the physical fitness test used, we measured blood pressure and heart rate immediately after the three most demanding fitness tests: 6MWT, SUSD, LW. We evaluated the hemodynamic parameters (the difference between the values measured immediately after exercise and resting values) for these tests. Analyzing the changes in heart rate it should be stressed that in the group of patients in the pre-test before the rehabilitation resting heart rate was $80.06 \mathrm{in} / \mathrm{min}$, $87.39 \mathrm{in} / \mathrm{min}$, which increased by $9.16 \%$. The measured pulse rate after application of the test amounted to 90.72 rehabilitation $\mathrm{u} / \mathrm{min}$ and $98.78 \mathrm{in} / \mathrm{min}$ (8.88\%). In tests, both before and after rehabilitation therapy systolic and diastolic blood ranged within physiological limits in all patients, $127-135 / 70-78 \mathrm{~mm} \mathrm{Hg}$ before the test to $128-149 / 73-79$ $\mathrm{mm} \mathrm{Hg}$ after the test.

Comparing the test results obtained according to the hemodynamic response, in most cases they did not show significant differences. However, better results were achieved by patients with a positive hemodynamic response after 6MWT and LW. Patients who achieved a greater distance $(522 \pm 89 \mathrm{~m}, p=0.003)$ showed an increase in blood pressure; in patients who walked a short distance (467 $\pm 72 \mathrm{~m}, p=0.01$ ), there was no change in blood pressure. The study found good intragroup repeatability. The smallest volatility, less than 5\% 6MWT concerned, in the next three tests, SG, SUSD, LW remained at around $10 \%$ (rate remained at the level of $p<0.05$ is statistically significant) (Table I).

In an attempt to get up and go [In] rated agility and dynamic balance test. Before the rehabilitation time needed to overcome a designated distance averaged $10.9 \mathrm{~s}$ and the rehabilitation of the average time the trial was $7.2 \mathrm{~s}$ (Fig. 1).

Another of the most aggravating trial was stand up and sit down (SUSD), which also improved from an average of 9 to 13 repetitions performed (Fig. 2). Changes start walking speed are reflected in the length of the distance covered in the 6-minute walk test (6MWT). Thus, in the group 
Tab. I. Within-test repeatability of the Fullerton test

\begin{tabular}{|c|c|c|c|c|c|c|c|c|c|c|}
\hline \multirow{3}{*}{$\begin{array}{l}\text { Samples } \\
\text { Sex }\end{array}$} & \multicolumn{4}{|c|}{ Measurements taken before rehabilitation } & \multicolumn{4}{|c|}{ Measurements taken after rehabilitation } & \multirow{2}{*}{\multicolumn{2}{|c|}{$\begin{array}{c}\text { Mean difference between } \\
\text { measurements taken } \\
\text { before and after }\end{array}$}} \\
\hline & \multicolumn{2}{|c|}{$\begin{array}{c}\overline{\mathrm{X}} \\
\text { arithmetic mean }\end{array}$} & \multicolumn{2}{|c|}{$\begin{array}{c}\text { SD } \\
\text { standard deviation }\end{array}$} & \multicolumn{2}{|c|}{$\begin{array}{c}\overline{\mathrm{X}} \\
\text { arithmetic mean }\end{array}$} & \multicolumn{2}{|c|}{$\begin{array}{c}\text { SD } \\
\text { standard deviation }\end{array}$} & & \\
\hline & $\mathrm{F}$ & M & $\mathrm{F}$ & M & $\mathrm{F}$ & M & $\mathrm{F}$ & M & $\mathrm{F}$ & M \\
\hline Arm Curl & 10 & 12 & 1.8 & 3.7 & 12 & 17 & 3.7 & 4 & 2 & 5 \\
\hline Chair Sit-and-Reach & 0.69 & 0.78 & 10.8 & 11.2 & 0.54 & 0.65 & 9.5 & 10.2 & 0.15 & 0.13 \\
\hline Back Scratch & -11.4 & -16.9 & 8.6 & 12.2 & -7.8 & -11.8 & 6.4 & 8.9 & -3.6 & -5.1 \\
\hline 6MWT & 498.7 & 564.5 & 76.2 & 86.3 & 512.5 & 598.3 & 63.4 & 71.9 & 13.8 & 33.8 \\
\hline
\end{tabular}

6MWT - 6-minute walk test

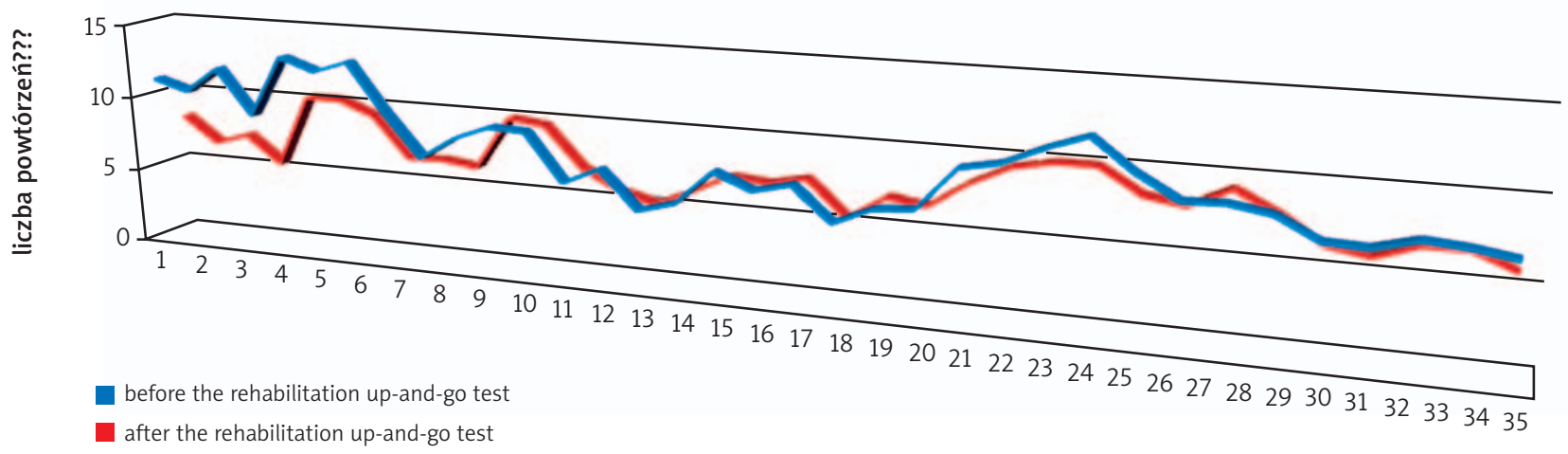

Fig. 1. Results of the 8-foot up-and-go test

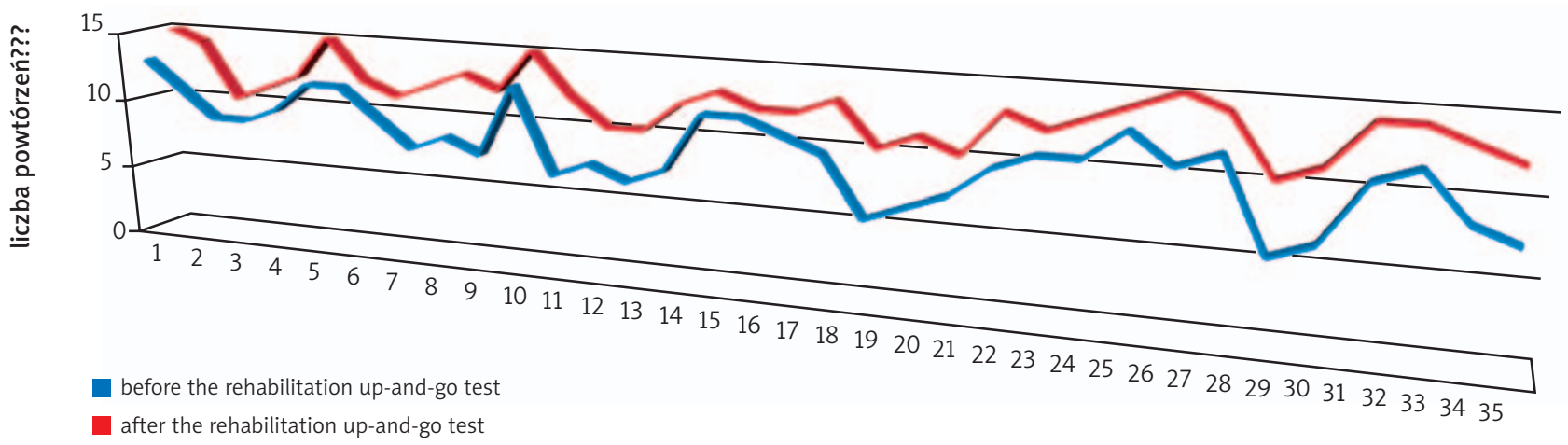

Fig. 2. Results of the 30-second chair sit-and-reach test

of 17 women the mean distance before rehabilitation was 498.7 and on the second test increased to $512.5 \mathrm{~m}$, which is an increase of $2.77 \%$. In the group of men we also saw an increase in the distance of $564.5 \mathrm{~m}$ to 598.3 , which represents a $6 \%$ increase of distance.

Figure 3 presents a summary of statistics for the size of image VC\% $\mathrm{FEV}_{1}$ - the chart shows the measurements made before and after the rehabilitation process, as well as the observed change in this period. From the point of view of practical applications, the most important are the results for the effect of rehabilitation (change of $\mathrm{FEV}_{1} \% \mathrm{VC}$ ).

To assess the significance of differences before and after physiotherapy, $t$-test for independent samples - the largest VC\% FEV 1 can be concluded that the change in the use of physiotherapy is greater. Also significant, not accidental, is the difference in VC\% after the physiotherapy preparatory process for thoracic surgery (Fig. 4).

\section{Discussion}

Most researchers employ rehabilitation programs lasting for a relatively long period of time: from $6[8,11]$ to 12 weeks [9]. In rare cases, the programs last for only 2 weeks [10]. The number of weekly training sessions is also varied and ranges from 3 to 5 days per week. One of the studies describes the employment of 7 sessions per week for 2 weeks [9]. The reported duration of training sessions varies as well. In most cases, the exercises lasted for 15 to 30 minutes; less frequently, the duration of the sessions was from 20 to 


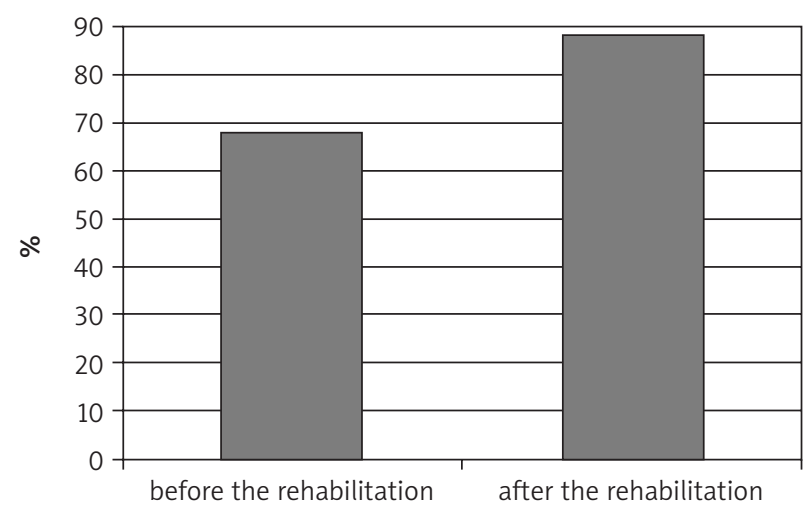

$\square \mathrm{FEV}_{1} \mathrm{VC} \%$

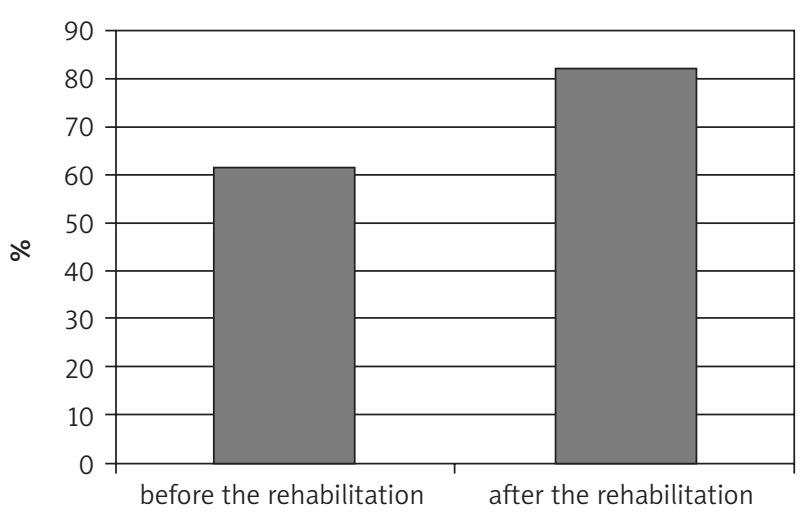

$\square$ mean VC\%
Fig. 3. Values of $\mathrm{FEV}_{1} \mathrm{VC} \%$ before and after the rehabilitation process

40 minutes [12]. Employing varied physiotherapeutic methods in the treated patient group most often results in the improvement of fitness parameters and, consequently, enhances the quality of life [9]. Courneya et al. [13] describe surgery patients undergoing rehabilitation consisting of walking and ergometer cycling. Their conclusion was that there is an interdependence between fatigue and exercise duration. Similar conclusions were reached by Dimeo et al. [10].

Standard clinical diagnostics includes trials evaluating the patients' level of physical fitness [14, 15]. However, comprehensive physical fitness evaluation has not as yet been used in the population of patients eligible for thoracic surgery. The few existing studies employed questionnaires asking the patients about their daily physical activity and their subjective evaluation of their physical fitness [16, 17]. No new research method enabling the assessment of all aspects of physical fitness in eligible patients has hitherto been developed; nor have the already existing tests recommended for specific age groups been used [18]. Considering the advanced age of patients and their low exertion tolerance, the present study employed the Fullerton Senior Fitness Test developed by Rikli and Jones. The test's authors prepared 6 mobility tasks assessing basic motor skills indispensable in the safe and independent performance of everyday activities. The Fullerton test, along with the norms for specific age groups, was developed for healthy persons [19]. In the present study, an attempt was made to use the Fullerton test in a group of patients qualified for thoracic surgical procedures. The test was selected for its short duration, broad scoring range, and the ease of performing its mobility tasks, which are based on everyday activities (e.g. standing up from a chair, putting on clothes). The fact that the test could be conducted within the hospital laboratory by only one examiner, and without the use of special equipment, was an additional advantage. The proposed fitness test was well received by the patients. They understood the purpose of each task well and had no trouble remembering the activities demonstrated by the physiotherapist. The patients
Fig. 4. Values of VC\% before and after the rehabilitation process

stressed the test's advantages: the short duration of exertion, the possibility of performing the tasks at one's own pace, and the lack of special equipment which, especially among elderly patients, may arouse unease and stress. The literature of the field indicates that methods as simple as the 30-Second Chair Stand or the Arm Curl exercises have not hitherto been used for assessing strength endurance in patients [20]. It appears, therefore, that the evaluation of relations between results obtained with the use of special equipment and results of the aforementioned muscular endurance tests, requires further research. In our study, good tolerance of the Fullerton test was observed. All patients performed the fitness tasks without any health-endangering consequences. No pathological signs of exercise intolerance related to the respiratory system, circulatory system or overloading of the locomotor system were observed during the performance of the test or after its completion.

Good repeatability and small variability of the obtained results were observed when determining the safety of the presented test as a new research method for evaluating thoracic surgery patients. The lack of pathological exercise intolerance symptoms during the performance of the mobility tasks and the fact that the test was well received by the patients may speak in favor of employing the Fullerton test as a new simple research method which comprehensively evaluates the physical fitness of patients who are being prepared for thoracic procedures. Moreover, the high repeatability of the test's results indicates that it could be useful for medical research as a reliable source of information about elderly patients qualified for lung parenchyma resection procedures.

The essential feature of the Fullerton test is its multidimensional evaluation of elderly patients' physical fitness, employed in order to detect difficulties in performing everyday activities. Such examination may be of great significance in the process of planning individualized thoracic surgery rehabilitation aimed at specific motor skills and in evaluating its effects. 


\section{Conclusions}

1. The Fullerton test is a useful tool for evaluating the physical fitness of patients eligible for thoracic surgery, and it may serve as a complement to comprehensive patient diagnostics.

2. Rehabilitation programs tailored to the needs of individual patients resulted in improved physical fitness (strength, flexibility, coordination, endurance).

3. The essence of the Fullerton test is its multidimensionality; supplemented with spirometric examination, it provides reliable information about thoracic surgery patients.

\section{References}

1. Bobbio A, Chetta A, Ampollini L, Primomo GL, Internullo E, Carbognani P, Rusca M, Olivieri D. Preoperative pulmonary rehabilitation in patients undergoing lung resection for non-small cell lung cancer. Eur J Cardiothorac Surg 2008; 33: 95-98.

2. Woźniewski M. Znaczenie aktywności ruchowej w rehabilitacji onkologicznej. Postępy Rehabilitacji 2004; 18: 2.

3. Wojciechowicz H. Usprawnianie chorych ze schorzeniami układu oddechowego. Rehabilitacja medyczna. Wydawnictwo Lekarskie PZWL, Warszawa 2001.

4. Kowalewski J, Dancewicz M. Rak płuca: leczenie chorych z ograniczoną rezerwą oddechową. Kardiochir Torakochir Pol 2008; 5: 413-417.

5. Cesario A, Ferri L, Galetta D, Cardaci V, Biscione G, Pasqua F, Piraino A, Bonassi S, Russo P, Sterzi S, Margaritora S, Granone P. Pre-operative pulmonary rehabilitation and surgery for lung cancer. Lung Cancer 2007; 57: 118-119.

6. Kochanowicz I. Lecznicza rehabilitacja oddechowa w chorobach płuc. PZWL, Warszawa 1990.

7. Droszcz W. Rehabilitacja w chorobach układu oddechowego. W: Kuch J (eds.). Rehabilitacja. Wydawnictwo Lekarskie PZWL, Warszawa 1998.

8. Mock V, Pickett M, Ropka ME, Muscari Lin E, Stewart KJ, Rhodes VA, McDaniel R, Grimm PM, Krumm S, McCorkle R. Fatigue and quality of life outcomes of exercises during cancer treatment. Cancer Pract 2001; 9: 119-127.
9. Dimeo FC, Tilmann MH, Bertz H, Kanz L, Mertelsmann R, Keul J. Aerobic exercise in the treatment of cancer patients after high dose chemotherapy and autologous peripheral steam cell transplantation. Cancer 1997; 79: 1717-1722.

10. Dimeo F, Stieglitz RD, Novelli-Fischer U, Fetscher S, Mertelsmann R, Keul J. Correlation between physical performance and fatigue in cancer patients. Ann Oncol 1997; 8: 1251-1255.

11. Durak EP, Lilly PC, Hackworth JL. Physical and psychological response to exercise in cancer patients. A two year follow-up survey with prostrate, leukemia and general carcinoma. J Exerc Physiol 1999; 2: 1-9.

12. Hayes S, Davies PS, Parker T, Bashford J. Total energy expenditure and body composition changes following peripheral blood stem cell transplantation and participation in an exercise programme. Bone Marrow Transplant 2003; 31: 331-338.

13. Courneya KS, Keats MR, Turner AR. Physical exercise and quality of life in cancer patients following high dose chemotherapy and autologous bone marrow transplantation. Psychooncology 2000; 9: 127-136.

14. Ponikowski P, Francis DP, Piepoli MF, Davies LC, Chua TP, Davos CH, Florea V, Banasiak W, Poole-Wilson PA, Coats AJ, Anker SD. Enhanced ventilatory response to exercise in patients with chronic heart failure and preserved exercise tolerance: marker of abnormal cardiorespiratory reflex control and predictor of poor prognosis. Circulation 2001; 103: 967-972.

15. Pawłowska-Jenerowicz W, Serwacka M, Dąbrowski M. Test spiroergometryczny - systematyczny wzrost popularności badania w obliczu zagrożenia epidemią niewydolności serca. Folia Cardiol 2003; 10: 727-731.

16. Oka RK, DeMarco T, Haskell WL. Perceptions of physical fitness in patients with heart failure. Prog Cardiovasc Nurs 1999; 14: 97-102.

17. Węgrzynowska K, Jankowska EA. Metody oceny sprawności i aktywności fizycznej chorych z niewydolnością serca. Fizjoterapia 2006; 14: 77-83.

18. Fletcher GF, Balady GJ, Amsterdam EA, Chaitman B, Eckel R, Fleg J, Froelicher VF, Leon AS, Pińa IL, Rodney R, Simons-Morton DA, Williams MA, Bazzarre T. Exercise standards for testing and training: a statement for healthcare professionals from the American Heart Association. Circulation 2001; 104: 1694-1740.

19. Rikli RE, Jones CJ. Functional fitness normative scores for community-residing older adults, ages 60-94. J Aging Phys Act 1999; 7: 162-181.

20. Rikli RE, Jones CJ. The development and validation of a functional fitness test for community-residimg older adults. J Aging Phys Act 1999; 7: 129-161. 